\title{
Un grupo nuevo de cerámica arcaica Griega ("Grupo H”) fabricado en Tartessos (Huelva, España)
}

\section{A new group of Archaic Greek Pottery ("Group H”) manufactured in Tartessos (Huelva, SW of Spain)}

\author{
Fernando González de Canales Cerisola \\ Adolfo J. Domínguez Monedero² \\ Jorge Llompart Gómez ${ }^{3}$ \\ Aurelio Montaño Justo ${ }^{4}$
}

Recibido: 02-02-2018

Aceptado: 11-09-2018

\begin{abstract}
Resumen
A la producción por griegos residentes en Huelva de vasos cerámicos caracterizados por una pasta verdosa amarillenta puede sumarse un segundo grupo, convencionalmente denominado "Grupo H", caracterizado por pastas amarillentas, anaranjadas o rojizas y frecuentes engobes rojos. El estudio preliminar de dos especímenes había ya apuntado una producción local de este nuevo grupo. Una ampliación de los análisis mediante activación neutrónica de otros 10 ejemplares establece de forma concluyente una estrecha semejanza con la composición química de los depósitos de arcillas próximos al hábitat. Asimismo, como en el grupo de pasta verdosa amarillenta, fue detectada una llamativa contaminación de algunos fragmentos cerámicos por metales preciosos, oro y especialmente plata. La representación de ambos grupos sugiere que un significativo porcentaje de los vasos cerámicos griegos arcaicos exhumados en Huelva fue manufacturado in situ.
\end{abstract}

Palabras clave: Grecia Oriental, alfares, análisis por activación neutrónica, plata.

\begin{abstract}
To the production by Greek residents in Huelva of pottery characterised by yellowish-green clay, a second ceramic group distinguished by yellowish, orange or reddish clay, and frequently red slipped, conventionally nominated "Group $\mathrm{H}$ " can now be added. The preliminary study of two pieces had already aimed at a local production of the new group. This fact is supported by the results of an additional study based on the Neutron Activation Analyses of 10 ceramic specimens conclusively indicating a close resemblance to the chemical composition of clays from local deposits near the habitat. Likewise, as in the group of the yellowish-green clay, a striking contamination with precious metals, gold and especially silver, was detected in some of the fragments. The representation of both groups suggests that a significant percentage of the Archaic Greek vessels found in Huelva was manufactured in situ.
\end{abstract}

Key words: Eastern Greece; pottery workshops; Neutron Activation Analysis; silver.

1 Correspondiente de la RAH. fgonzalezdecanales@yahoo.es /ORCID iD: http://orcid. org/0000-0003-1485-8641.

2 adolfo.dominguez@uam.es / ORCID iD: http://orcid. org/0000-0002-2059-1173.
3 Licenciado en Historia. jorge-llompart@hotmail.com / ORCID iD: http://orcid. org/0000-0001-6681-0004.

4 Licenciado en Historia. aureliomontano@gmail.com / ORCID iD: http://orcid. org/0000-0003-1422-2643. 


\section{INTRODUCTION}

It has recently been determined that a group of Archaic Greek pottery characterised by yellowishgreen clay had been manufactured by Greek residents in Huelva, Spain (González de Canales and Llompart, 2017). This conclusion was based on several facts: the exclusivity of the location, the formal and decorative features, the manufacturing anomaly of an amphora, and finally, the clay composition yielded by both $\mathrm{X}$ Ray Diffraction (XRD) and Instrumental Neutron Activation Analyses (INAA). The results of the latter method were consistent with the chemical composition of the Miocene clay deposits (Gibraleón Clays Formation) next to the habitat, except for gold and silver found in the ceramics samples, undetected in the samples from those deposits. The precious metals contamination can be justified by the intense exploitation of aureo-argentipherous minerals in the city-emporium over several centuries. The results of the INAA also revealed that two samples of another abundant ceramics group characterised by yellowish, orange or reddish clay colour and frequent red slip, conventionally designated "Group H" ("H" for the first letter in "Huelva"), showed a similar chemical composition (González de Canales and Llompart, 2017: 126 and 139-142). Decorations are generally limited to bands and wide red slips, with the occasional case of tongues, circles, crosses and dots of the same colour. Seldom, red is applied over white slips. Just like in the yellowishgreen clay pottery, ceramics with "Group H" features thrive in symposium vessels (kraters, dinoi, oenochoai, and, above all, cups), without missing aryballoi, lamps, amphorae, and others for diverse purposes. In order to ascertain the local manufacture of this second ceramic group, an enhancement of the analytical determinations was thought necessary. This paper will try to justify such requirement by providing the results of the study from 10 other specimens.

\section{MATERIALS AND METHODS}

A chemical analysis of 10 specimens, ascribed to Group "H" by their characteristics, was carried out by INAA: three cups, two bowls, one dinos, two kraters and two amphorae. Their descriptions, drawings and pictures are shown in a catalogue at the end of this text. Five of the specimens had been taken in 1989 from a retrieval of materials in the terrain currently assigned to 4 Méndez Núñez St. The other five came from the regular excavation in 1998 of the terrain at 7-13 Méndez Núñez St / 12 Las Monjas Sq, where a Phoenician sanctuary was documented (Osuna Ruiz et alii, 2001). Both sites, very close to each other, are located in the historic centre of the city (Fig. 1). From the latter terrain a bowl has also been selected (catalogue number 11), without being analysed but presenting the same characteristics of Group " $\mathrm{H}$ " for its quality, clay colour and red slip. The interest of this specimen lies in the fact that it shows Greek graffiti (see Addendum).

Although, as in the case of the yellowish-green clay pottery, analysed ceramics were found associated to other Greek vases of well-established chronology (Circle of the Gorgon Painter, komast cups, Little Master cups, etc.), the lack of stratification in the former terrain and the fact that the stratigraphic position of the analysed ceramic from the latter is unpublished suggests their ascription to a chronological frame between the end of the 7th century $\mathrm{BC}$ and beginning of the second half of the 6th century BC, the period comprising Greek vases from Huelva linked to direct Greek activities. This time frame could be reduced by half a century if we are to consider that pottery with this group's features tends to appear preferably between ca. 590/580 B.C. and ca. 540 B.C. in published stratigraphies (Cabrera Bonet, 1990: 62, 71 and 74).

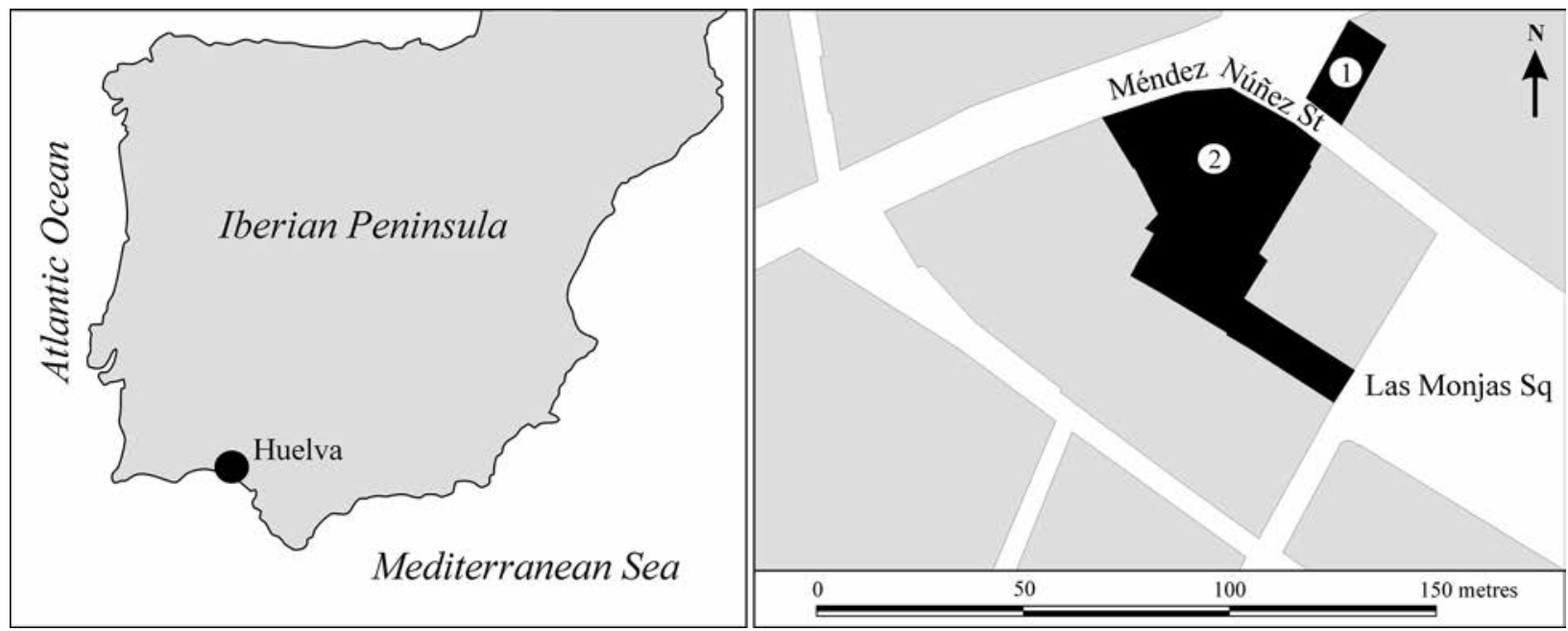

Figure 1. Huelva sites cited. 1 = 4 Méndez Núñez St (current number); 2 = 7-13 Méndez Núñez St / 12 Las Monjas Sq. 
The methodology used in the clay analysis was as follows. A 1-2 g sample from each pottery fragment was taken for analysis. The upper layers were scraped out with an agate knife to eliminate decoration pigments as well as media attachments, using gloves in order to avoid contamination, and then the samples were carefully rinsed with distilled water and absolute alcohol. After drying, the samples were finely pulverised in an agate mortar and sent to a world-class laboratory. The chemical analysis was done by Activation Laboratories Ltd. (ActLabs, Ancaster, Ontario, Canada), accredited to the standard ISO/IEC 17025 Quality System.5 The analytical package included a suite of 35 chemical elements (Code 1D Enhanced $\mathrm{Au}+34){ }^{6}$

\section{RESUlts}

The experimental results showed that all 10 specimens analysed in this work (Fig. 2 samples 1-10), as well as samples from one cup and one bowl (Fig. 2 samples 11-12), previously reported (González de Canales and Llompart, 2017: Fig. 18 samples 5-6), have similar concentration ranges for most of the chemical elements falling within the range of the clay samples from local deposits (Fig. 2 samples 13-14), also reported (González de Canales and Llompart, 2017: Fig. 18 samples 7-8), particularly for major (Ca, $\mathrm{Fe}$ and $\mathrm{Na}$ ), minor and trace elements ( $\mathrm{Co}, \mathrm{Cr}, \mathrm{Cs}, \mathrm{Hf}$, $\mathrm{Rb}, \mathrm{Sb}, \mathrm{Sc}, \mathrm{Th}$ and $\mathrm{Yb})$, as well as rare earths (Ce, $\mathrm{Eu}$, $\mathrm{La}, \mathrm{Lu}, \mathrm{Nd}$ and $\mathrm{Sm}$ ). The following elements were found below their detection limits not only in the ceramic samples but also in the natural clays materials: $\mathrm{Hg}(<1 \mathrm{ppm}), \operatorname{Ir}(<5 \mathrm{ppm})$ with one exception (sample 8), Ni (<20 ppm), Se (<3 ppm), Sn $(<0.02 \mathrm{ppm})$, $\mathrm{Sr}(<0.05 \mathrm{ppm}), \mathrm{Ta}(<0.5 \mathrm{ppm}), \mathrm{Tb}(<0.5 \mathrm{ppm}), \mathrm{W}$ $(<1 \mathrm{ppm})$ and $\mathrm{Zn}(<50 \mathrm{ppm})$. Moreover, the relatively large range of concentrations presented by a few elements (As, $\mathrm{Ba}, \mathrm{Br}$ and $\mathrm{U}$ ) also seems to appear in the clay samples from the deposits. Some specimens (Fig. 2 samples 1, 3, 5, 8 and 12) showed a discrete presence of gold (up to $17 \mathrm{ppb}$ ) while others (Fig. 2 samples 1 , $3,5,6,8,10$ and 11) have a significant amount of silver (up to $465 \mathrm{ppm}$ ), whereas precious metals were not detected in the clay deposits samples (Fig. 2 samples 13-14), as expected in marine sedimentary clays.

\begin{tabular}{|c|c|c|c|c|c|c|c|c|c|c|c|c|c|c|c|}
\hline Element & D. limit & 1 & 2 & 3 & 4 & 5 & 6 & 7 & 8 & 9 & 10 & 11 & 12 & 13 & 14 \\
\hline $\mathrm{Ag} \mathrm{ppm}$ & 5 & 465 & $<5$ & 53 & $<5$ & 96 & 11 & $<5$ & 25 & $<5$ & 15 & 80 & $<5$ & $<5$ & $<5$ \\
\hline As ppm & 0.5 & 15.7 & 7 & 23.6 & 17.1 & 17.8 & 16.3 & 21.9 & 7.8 & 18.0 & 16.1 & 55.7 & 23.4 & 6.8 & 12.0 \\
\hline Au ppb & 2 & 7 & $<2$ & 13 & $<2$ & 14 & $<2$ & $<2$ & 10 & $<2$ & $<2$ & $<2$ & 17 & $<2$ & $<2$ \\
\hline Ba ppm & 50 & $<50$ & 360 & 310 & 610 & 500 & 510 & 420 & 650 & 500 & 640 & 660 & 520 & 150 & 360 \\
\hline Br ppm & 0.5 & 6.6 & 0.8 & $<0.5$ & 6.8 & $<0.5$ & $<0.5$ & $<0.5$ & 2.9 & 3.8 & 1.9 & 8.0 & $<0.5$ & $<0.5$ & 3.5 \\
\hline $\mathrm{Ca} \%$ & 1 & 7 & 12 & 7 & 12 & 10 & 11 & 11 & 10 & 11 & 15 & 10 & 7 & 5 & 12 \\
\hline Ce ppm & 3 & 69 & 60 & 69 & 53 & 60 & 62 & 68 & 62 & 60 & 63 & 57 & 59 & 61 & 52 \\
\hline Co ppm & 1 & 8 & 10 & 13 & 9 & 9 & 9 & 10 & 10 & 9 & 10 & 11 & 9 & 9 & 9 \\
\hline Cr ppm & 5 & 112 & 94 & 103 & 102 & 94 & 90 & 103 & 94 & 103 & 86 & 80 & 80 & 58 & 72 \\
\hline Cs ppm & 1 & 5 & 7 & 4 & 4 & 6 & 6 & 9 & 5 & 8 & 5 & 5 & 8 & 4 & 4 \\
\hline Eu ppm & 0.2 & 0.6 & 1.0 & 1.1 & 0.9 & 1.1 & 0.9 & 1.1 & 1.1 & 0.9 & 1.0 & 1.0 & 1.2 & 1.0 & 0.7 \\
\hline $\mathrm{Fe} \%$ & 0.01 & 3.71 & 3.41 & 3.16 & 3.51 & 3.28 & 3.45 & 3.88 & 3.60 & 3.43 & 3.72 & 3.61 & 3.29 & 3.27 & 2.93 \\
\hline Hf ppm & 1 & 6 & 4 & 7 & 6 & 5 & 6 & 5 & 5 & 5 & 4 & 6 & 7 & 8 & 6 \\
\hline $\mathrm{Hg}$ ppm & 1 & $<1$ & $<1$ & $<1$ & $<1$ & $<1$ & $<1$ & $<1$ & $<1$ & $<1$ & $<1$ & $<1$ & $<1$ & $<1$ & $<1$ \\
\hline Ir ppb & 5 & $<5$ & $<5$ & $<5$ & $<5$ & $<5$ & $<5$ & $<5$ & 8 & $<5$ & $<5$ & $<5$ & $<5$ & $<5$ & $<5$ \\
\hline La ppm & 0.5 & 37.2 & 34.5 & 35.8 & 34.2 & 34.2 & 33.6 & 37.9 & 35.7 & 34.9 & 36.4 & 30.3 & 30.5 & 30.0 & 27.1 \\
\hline Lu ppm & 0.05 & 0.34 & 0.33 & 0.45 & 0.32 & 0.41 & 0.32 & 0.39 & 0.27 & 0.39 & 0.36 & 0.20 & 0.33 & 0.21 & 0.26 \\
\hline Mo ppm & 1 & $<1$ & $<1$ & $<1$ & 2 & $<1$ & $<1$ & $<1$ & $<1$ & $<1$ & $<1$ & $<1$ & $<1$ & $<1$ & $<1$ \\
\hline $\mathrm{Na} \%$ & 0.01 & 0.81 & 0.53 & 0.94 & 0.90 & 0.59 & 0.60 & 0.82 & 0.73 & 0.80 & 0.70 & 0.66 & 0.64 & 1.02 & 0.47 \\
\hline $\mathrm{Nd} \mathrm{ppm}$ & 5 & 30 & 32 & 35 & 16 & 29 & 38 & 30 & 30 & 29 & 17 & 27 & 27 & 24 & 25 \\
\hline Ni ppm & 20 & $<20$ & $<20$ & $<20$ & $<20$ & $<20$ & $<20$ & $<20$ & $<20$ & $<20$ & $<20$ & $<20$ & $<20$ & $<20$ & $<20$ \\
\hline $\mathrm{Rb}$ ppm & 15 & 76 & 136 & 111 & 95 & 73 & 77 & 120 & 160 & 88 & 116 & 70 & 43 & 88 & 120 \\
\hline Sb ppm & 0.1 & 1.6 & 2.6 & 1.0 & 1.2 & 1.7 & 2.4 & 1.7 & 1.7 & 1.3 & 1.9 & 3.1 & 2.3 & 1.2 & 0.9 \\
\hline Sc ppm & 0.1 & 12.3 & 11.1 & 11.9 & 10.9 & 11.3 & 10.6 & 12.0 & 11.4 & 11.2 & 11.9 & 12.1 & 11.5 & 11.8 & 9.4 \\
\hline Se ppm & 3 & $<3$ & $<3$ & $<3$ & $<3$ & $<3$ & $<3$ & $<3$ & $<3$ & $<3$ & $<3$ & $<3$ & $<3$ & $<3$ & $<3$ \\
\hline Sm ppm & 0.1 & 4.9 & 4.3 & 45 & 4.3 & 4.4 & 4.4 & 5.0 & 4.4 & 4.6 & 4.6 & 4.6 & 4.7 & 4.9 & 4.4 \\
\hline Sn $\%$ & 0.02 & $<0.02$ & $<0.02$ & $<0.02$ & $<0.02$ & $<0.02$ & $<0.02$ & $<0.02$ & $<0.02$ & $<0.02$ & $<0.02$ & $<0.02$ & $<0.02$ & $<0.02$ & $<0.02$ \\
\hline $\mathrm{Sr} \%$ & 0.05 & $<0.05$ & $<0.05$ & $<0.05$ & $<0.05$ & $<0.05$ & $<0.05$ & $<0.05$ & $<0.05$ & $<0.05$ & $<0.05$ & $<0.05$ & $<0.05$ & $<0.05$ & $<0.05$ \\
\hline a ppm & 0.5 & $<0.5$ & $<0.5$ & $<0.5$ & $<0.5$ & $<0.5$ & $<0.5$ & $<0.5$ & $<0.5$ & $<0.5$ & $<0.5$ & $<0.5$ & $<0.5$ & $<0.5$ & $<0.5$ \\
\hline Tb ppm & 0.5 & $<0.5$ & $<0.5$ & $<0.5$ & $<0.5$ & $<0.5$ & $<0.5$ & $<0.5$ & $<0.5$ & $<0.5$ & $<0.5$ & $<0.5$ & $<0.5$ & $<0.5$ & $<0.5$ \\
\hline Th ppm & 0.2 & 9.9 & 7.7 & 8.5 & 7.6 & 9.6 & 8.3 & 8.8 & 9.2 & 8.2 & 8.8 & 10.6 & 10.6 & 10.1 & 8.4 \\
\hline U ppm & 0.5 & 3.4 & 2.2 & 4.4 & 4.1 & 4.1 & 3.8 & 4.3 & 2.9 & 2.6 & 3.8 & 3.6 & 3.6 & 2.5 & 2.5 \\
\hline W ppm & 1 & $<1$ & $<1$ & $<1$ & $<1$ & $<1$ & $<1$ & $<1$ & $<1$ & $<1$ & $<1$ & $<1$ & $<1$ & $<1$ & $<1$ \\
\hline $\mathrm{Yb}$ ppm & 0.2 & 2.1 & 2.2 & 2.7 & 2.3 & 2.0 & 2.3 & 3.0 & 2.2 & 1.9 & 2.2 & 2.5 & 2.5 & 2.9 & 2.3 \\
\hline Zn ppm & 50 & $<50$ & $<50$ & $<50$ & $<50$ & $<50$ & $<50$ & $<50$ & $<50$ & $<50$ & $<50$ & $<50$ & $<50$ & $<50$ & $<50$ \\
\hline Mass g & & 1.36 & 1.28 & 1.35 & 1.44 & 1.59 & 1.34 & 1.22 & 1.19 & 1.50 & 1.47 & 1.25 & 1.14 & 1.34 & 1.39 \\
\hline
\end{tabular}

Figure 2. Results of the Neutron Activation Analysis (Actlabs). D. limit = Detection limit. Pottery samples: 1-10 = catalogue numbers 1-10; 11 and $12=$ samples 5 and 6 in González de Canales and Llompart 2017. Clay deposit samples: 13 and $14=$ samples 7 and 8 in González de Canales and Llompart 2017.

5 The methodology followed by Actlabs can be consulted at: http://www .actlabs.com/page. aspx $?$ page $=496 \&$ app $=226 \&$

6 Report A16-13703. cat $1=549 \& \mathrm{tp}=12 \& \mathrm{k}=$ no \&menu $=64$. 
Specifically, sample 1 differs from the rest by showing the maximum level of silver (465 ppm) and by being the only one where barium was not detected by INAA. The yellowish-green clay pottery consistently displayed similar results.

\section{DiscusSION}

The preliminary XRD analysis of two specimens ascribed to "Group H" yielded a mineralogical composition compatible with that of local clay deposits. The occurrence of calcite in these specimens indicated that the firing temperature was most likely under $900^{\circ} \mathrm{C}$, because calcite did not react with clay minerals to produce the formation of high temperature phases (diopside, anorthite and gehlenite) as in the case of the yellowishgreen pottery (González de Canales and Llompart, 2017: 135,139 and 142).

The results of the INAA showed that the chemical composition of the pottery is consistent with that of the clays from local deposits, both in the concentration ranges of detected elements and elements below the detection limits of the technique. In fact, the only difference is the lack of detection of precious metals in the claybeds. The geochemical resemblance between pottery and samples from the clay deposits is evident through simple statistical data processing. As observed in Figure 3, when the average concentrations of chemical elements found in the pottery above their detection limits are projected against those of the same elements in the claybeds, a strong positive correlation ratio appears $\left(\mathrm{R}^{2}=0.83\right)$. This suggests that the clay deposits could be the source of the ceramic's raw materials. All the elements match relatively well with the general trend or regression line except for the precious metals. Indeed, gold and most notably silver have an anomalous statistical occurrence with a remarkable deviation from the average value of up to $130 \mathrm{ppm}$ in the case of silver measured in the pottery samples, whereas in the samples from the clay deposits both metals were undetected.

Concerning pottery contamination by precious metals, two assumptions were put forward. In the first one, the claybeds taken for the ceramic manufacture could have become mixed in the habitat with the aureoargentipherous minerals from the mining sites. However, in the case of a specimen of yellowish-green clay with 243 ppm of silver (González de Canales and Llompart, 2017: Fig. 18 sample 2), as well as in sample 1 of "Group H", with 465 ppm of silver, this process would imply an excessive mineral mix to be considered

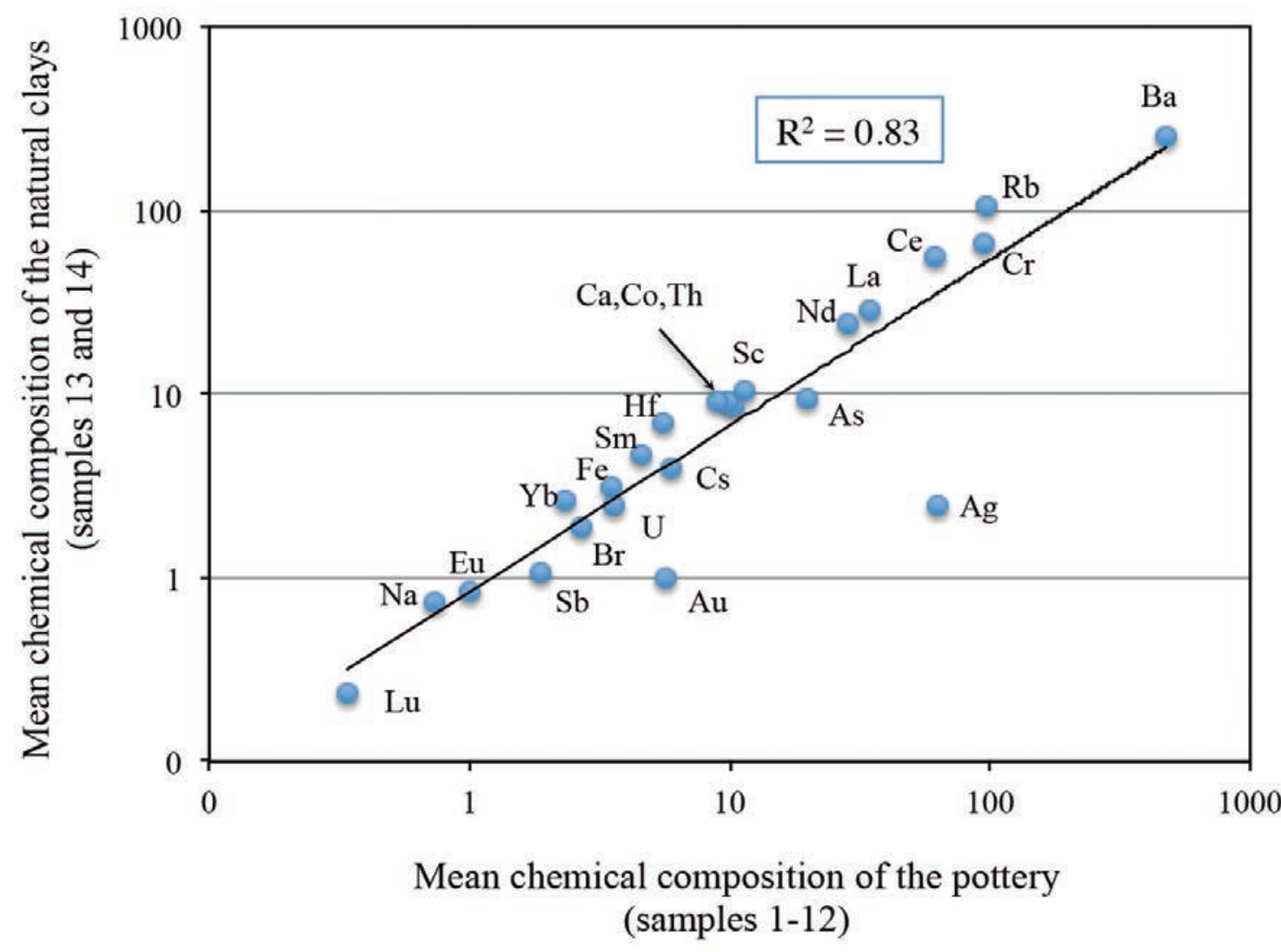

Figure 3. Linear correlation diagram showing the relationship between the average chemical composition of the pottery and the clay samples from local deposits. Data points for $\mathrm{Ag}$ and $\mathrm{Au}$ lie below the regression line, indicating that they are anomalously concentrated in the pottery samples. 
merely accidental. Most plausibly, at least in these two cases, contamination might have happened later during the more than two and a half millennia that the ceramic shards remained underground exposed to watery fluxes mobilising contaminated silvery sediments. This explanation, proposed for Israelite and Corinthian pottery, is backed by the high silver concentration $(108.4 \pm 3.6$ ppm) in the clay base of a jug ascribed to Early Iron Age at Tel Dor containing a silver deposit (Adan-Bayewitzet alii, 2006 and 2010).

Ceramic sample 1 deserves an additional comment for its unusually high silver concentration (465 ppm) and because this is the only sample in which barium was below the detection limit. The high silver concentration suggests processes of metal fixation to the clayish structure, as in the Tel Dor jug mentioned above. It can be conjectured that the ceramic fragment must have remained close to silver ore or metallurgical slags from which silver could have been released gradually by lixiviation, thus contaminating the adjacent ceramics. It is seemingly more difficult to explain the low barium concentration $(<50 \mathrm{ppm})$ in such sample. Barium is one of the few elements (together with As, $\mathrm{Br}$ and $\mathrm{U}$ ) showing remarkable variations in all sample groups. The wide value dispersion presented by barium concentrations could be explained because this element is typically concentrated in barite (BaSO4), an ancillary mineral that usually appears scattered throughout the sediments. Therefore, barium concentration is dependent upon the occurrence of barite grains in the samples, all of which introduces certain value heterogeneity. Nevertheless, the coincidence with the remaining chemical elements suggests a common origin and, obviously, the high silver concentration, together with the $7 \mathrm{ppb}$ of gold, links the specimen to a site rich in precious metals, such as Huelva: a specialised centre for silver metallurgy.

\section{Conclusions}

The chemical composition, as determined by INAA, of 10 Greek vases ascribed to the conventionally nominated "Group H" showed a fair correlation with the geochemical profile of the local clay deposits, thus confirming an Archaic Greek pottery production in Huelva, as already suggested on the basis of two specimens previously studied. This group characterised by yellowish, orange or reddish clay and frequent red slips, is well represented among Archaic Greek vases exhumed in the city; being equally numerous those of yellowishgreen clay, also locally produced. Therefore, it may be concluded that a significant percentage of all Archaic Greek vases found in Huelva were actually manufactured in situ. Although the possibility of imports similar to "Group H" vases cannot be left out, since their features are less specific than in the yellowish-green group, it is very suggestive that the 12 specimens analysed correspond, without exception, to local productions. An additional remark is that their reddish slips, easily detachable, recall those of Phoenician pottery from the same site, to the point that an atypical fragment may end up being impossible to qualify as either Greek or Phoenician. It is conceivable that Greek potters applied a usual decorative technique to much of their production in a location where Phoenicians had settled three centuries earlier. Both yellowish-green group and "Group H" vases seem to be preferably aimed at supplying the needs of tableware for Greek residents without depending on imports. This loyalty to their traditions justifies the establishment of potters' workshops during a period in which the Greeks, according to written sources originated in the Archaic Epoch as well as archaeological finds, kept a close relationship with Tartessos (González de Canales, 2014).

\section{AdDENDUM: GREEK GRAFFITTI ON A HANDLED BOWL (CATALOGUE NUMBER 11, Fig. 6.11)}

\section{Adolfo J. Domínguez Monedero}

It seems beyond any doubt that the two fragments we are about to analyse belong to the same vessel and consequently should be treated as such.

The vessel presents the particular feature of graffito signs on both sides, which, as we shall try to show, belong clearly to a Greek alphabet.

The study is started by the internal side.

Letter size: $1 \mathrm{~cm}$.

A distinct sign is composed of two lines in acute angle located in the upper part. Both lines have the same length. According to the alphabet in which it could have been written, the sign may correspond to a gamma or else to a lambda, with no option of favouring any of these two possibilities for the time being. On the right, there is another line, well defined, presenting a horizontal path which may correspond to some Greek letter, although it is possible to suggest that we are facing two numerals, as if it were a trademark. In the alphabetic numeral system, gamma would stand for 3, whereas lambda would mean 30. It has also been suggested that the horizontal line could be equivalent to 10 (Johnston 1979: 31); but it could also be the initial of some vessel name, followed by a numeral, though we think it is less likely.

\section{External side.}

Letter size: $1 \mathrm{~cm}$.

On the external side three out of four signs are clearly distinguished. Starting from the left, we perceive a sign describing a rightward curve with a wider trace on the upper part which gets narrower as it goes down. A close observation of the piece, as well as its picture, seems to discard the accidental nature of this sign; in the same way, both size and ductus are very similar to the ones of the third letter. It also presents a round line, so that, in principle, it does not seem to be caused by a casual abrasion on the surface of the vessel. Therefore, I believe we should treat it as a letter, or at least as an 
effort to represent one. The problem is that with this clearly semicircular shape it might also be a gamma, proper to many archaic alphabets, but also a pi, usual in Cretan alphabets at least in stone inscriptions (Jeffery 1990: 308, Table of Letters). The reading of the following letters makes, however, any of these possibilities problematic because there are not many reading options, while if we discard it there remains at least a reasonable chance. Consequently, I think we may interpret the sign as perhaps a failed and unconcluded attempt to write a letter. Of course, there is always the possibility of accidental abrasion in spite of our previous remarks.

Reading becomes clearer with the remaining letters. Hence, from left to right, we would have: one alpha, one theta and another alpha, the former two partially cut by the fracture of the vessel and the latter, virtually com-

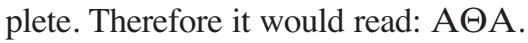

Also in this case, certain interesting comments can be made. First, referring to the alphas, both are different, since the transversal trace of the first one goes upward from left to right, while the direction of the second is opposite; this is, it goes upward from right to left. In general, the sense of the first alpha usually corresponds to inscriptions written from right to left, while the second usually appears in epigraphs written in the opposite direction. It is not infrequent that both types of alpha are shown in the same epigraph, although it is more common for them to be done with boustrophedon inscriptions and their orientation would follow the text direction in each line, alternatively, dextrorse and sinistrorse.

As to the theta, it is of the "cart-wheel" type, the usual shape in archaic inscriptions, though from the second half of the 6th century BC the cross-barred theta became more frequent. The theta with a dot inside is found later (Jeffery 1990: 29) so that the shape of this letter matches well with the chronology assigned to the support.

Although the second alpha presents a larger separation from the theta than the first one, there is no trace of any other letter in between, in spite of the fact that the vessel is broken in that area, there does not seem to be enough distance to justify the existence of another letter. In the same way, the fragment is also broken on the right of the second alpha, so that we cannot ascertain whether the text continued, as it might have, or was interrupted. Consequently, we reaffirm the reading $\mathrm{A} \Theta \mathrm{A}[\ldots$ for the present text.

With that limited number of letters the chances for interpretation are not many; however, what comes first to one's mind is the name of the goddess Athena, in any of the possible declensions (nominative, or more likely perhaps, genitive or dative). We should not miss the fact that the Huelva area, where the fragment comes from, is well known for having hosted places of worship during the Archaic period (Osuna et al. 2001: 177-188; Domínguez Monedero 2013: 11-42), all of which makes this alternative possible. In this case, the text would be written in Doric dialect 'A $\theta$ óvo, instead of Ionic, in which case it would rather have been 'A $\theta$ pvoí or 'A $\theta$ í $\eta$. Nonetheless, we cannot forget that archaic inscriptions in the city of Athens proper, the form 'A $\theta \alpha ́ v \alpha$ (i.e.: $I G \mathrm{I}^{3}$ 571, 647, 718, 1469, etc.) was the one used when referring to the goddess Athena, although not exclusively, as we shall see further on. The letter forms are generic enough to neglect additional information about the possible origin of the author of the inscription, although we are more inclined toward a text written in Doric dialect, not being the only case extant in Huelva, after the find of a dedication to Heracles in Doric dialect and Cnidian script (Domínguez Monedero 2010: 60-61).

Likewise, given the fragmentary nature of the inscription, it could also be the case of a theophoric name, based on the name of the goddess, an alternative that cannot be discarded.

Although of a different nature, since it is an inscription painted before firing, the name Athena is written as shown in one of the first Greek fragments published in Huelva, one Attic olpe attributed to Kleitias, found in 10 Puerto St, in which the name of the goddess can be read as ['A] $\theta \varepsilon v \alpha i ́ \alpha$ (Olmos and Cabrera 1980: 5-14; De Hoz García-Bellido 2014: 351-352).

These graffiti, thus, written in Greek on a locally manufactured Greek-type pottery are an additional proof of the Greek involvement in the emporion established in the city of Huelva. Their possible religious connections fit well with other cases of Greek graffiti found in Huelva.

\section{Catalogue}

Abbreviations: LN. = Label Number; Pr. = Provenance; Fr. = Fragment; H. = Height; W. = Width; D. = Diameter; Th. $=$ Thickness; $\mathrm{O}=$ Outside; $\mathrm{I}=$ Inside.

All sizes in centimetres.

\section{Cup (Fig. 4.1).}

LN. MN4/1989/104. Pr. 4 Méndez Núñez St (current number). Fr. of lip, body and handle. H. 3.7. W. 5.2. D. 17. H. lip 1.6. D. handle circular cross-section 0.9. Th. lip 0.2 at top and 0.5 at lower end. Th. body 0.4 . O: lip reserved of same colour as clay; 10R4/6 red band on body just below lip; handle-zone reserved; lower body and outer surface of rest handle conserved red slipped. I: slipped of same red colour as outside decoration. Clay 5YR7/8 reddish yellow.

\section{Cup (Fig. 4.2).}

LN. MN7/1998/14. Pr. 7-13 Méndez Núñez St / 12 Las Monjas Sq. Fr. of body and foot. H. preserved vase 3. H. foot 2.1. D. top foot 4. D. base 6.5. W. circular standing surface 1 . Th. body at upper breaking edge 0.4 . O: foot and body $2.5 \mathrm{YR} 8 / 4$ red slipped; standing surface 
reserved of same colour as clay. I: body red slipped as outside decoration; foot reserved of same colour as clay. Clay 7.5YR6/8 reddish yellow.

\section{Cup (Fig. 4.3).}

LN. 98/I/231. Pr. 7-13 Méndez Núñez St / 12 Las Monjas Sq. Fr. of body and foot. H. preserved vase 3.5 . H. foot 1.8. D. top foot 3.2. D. base 6.3. D. little knob at floor centre 1 . W. circular resting foot surface 0.9 , but because it is slightly raised towards the inside, the only support occurs on outer edge. Th. body at upper braking edge 0.5. Th. foot between 0.5 and 0.4. O: preserved body and foot 7.5YR4/4 between brown and dark brown slipped with zones where slip is detached showing same colour as clay. I: preserved body and foot slipped as outside. Clay $2.5 \mathrm{Y} 7 / 4$ pale yellow.

\section{Bowl (Fig. 4.4)}

LN. MN4/1989/45. Pr. 4 Méndez Núñez St (current number). Fr. of rim, body and foot allowing a complete reconstruction. Rim with flat top surface. Groove below rim. Slightly splayed foot with concave underside surface. H. vase 5.4. D. 16. W. top rim surface 0.7 . H. foot 0.7 . D. base 7 . Th. body 0.55 . Th. floor inner breaking edge 0.2 . O: on a $10 \mathrm{YR} 8 / 1$ white slipped background, $7.5 \mathrm{YR} 5 / 8$ strong brown cross strokes on top rim surface with low adherent paint. I: on the same white slip as outside, broadband occupies rim and upper body; below, two narrower bands, a broadband and, on the bottom, another two narrow bands of same strong brown colour as rim strokes. Clay 10YR5/8 yellowish brown.

\section{Bowl (Fig. 4.5).}

LN. MN/1989/54. Pr. 4 Méndez Núñez St (current number). Fr. of rim and body. H. 6.7. W. 5.5. Estimated D. 15.5. Th. body 0.45 . O: 2.5 YR5/8 red band on upper body; preserved lower part of body slipped with same red colour; reserved zones $2.5 \mathrm{Y} 7 / 4$ pale yellow. I: broadband on upper body and another one on lower part same red colour as outside decoration; reserved zones as in outside. Clay 7.5YR5/8 strong brown.

\section{Dinos (Fig. 5.1).}

LN. MN7/1998/26. Pr. 7-13 Méndez Núñez St / 12 Las Monjas Sq. Fr. of rim and body. H. 5.5. W. 7.2. Rim thickened inside with flat top surface. D. outer edge of rim 21. W. top rim surface 2. Maximun Th. rim 1.2. Th. body 0.6. O: rim and body $2.5 \mathrm{YR} 4 / 8 \mathrm{red}$ slipped. I: rim band of same red colour as outside decoration; rest reserved of same colour as clay. Clay 7.5YR7/6 reddish yellow.

\section{Krater (Fig. 5.2).}

LN. MN7/1998/7. Pr. 7-13 Méndez Núñez St / 12 Las Monjas Sq. Fr. of rim, neck and body. Thickened rim with top flat surface. H. 6.7. W. 8.9. D. 29. H. rim 0.6. W. top rim surface 1.1. H. neck 1.6. Th. upper neck
0.8 decreasing to 0.6 at lower end. Th. upper body 0.7 , decreasing to 0.6 at lower breaking edge. O: rim 2.5YR5/8 red slipped including top surface; broadband on body and, below, remains of a circular shaped figure of the same red colour; reserved zones 2.5Y7/4 pale yellow. I: neck red slipped as outer decoration; rim and body reserved same colour as outside. Clay 7.5YR6/8 reddish yellow.

\section{Krater (Fig. 5.3).}

LN. MN4/1989/129. Pr. 4 Méndez Núñez St (current number). Fr. of base with low ring-shaped foot. H. preserved vase 1.9. H. foot 1.3. D. base 11.5. W. circular standing surface 1.1 . Th. floor 0.6 at periphery and 0.4 at inner breaking edge. Th. foot between 1.5 at the upper end and 1.1 at the circular standing surface. $O$ : foot 2.5YR4/8 red slipped; standing surface reserved same colour as clay. I: floor reserved as outside except for a peripheral band of same red colour as outside foot; foot reserved same colour as clay. Clay 10YR8/4 very pale brown.

\section{Amphora (Fig. 6.1)}

LN. MN4/1989/48. Pr. 4 Méndez Núñez St (current number). Fr. of neck, shoulder and a complete handle. Handle inserts in rim and shoulder. Everted rim with top flat surface. H. 11.4. W. 9.2. D. 13. H. rim 1. W. top rim surface 1. H. neck 5.5. Handle oval cross-section $2.6 \mathrm{x}$ 1.2. Handle projection 3. Th. outer edge of rim 0.4 . Th. neck 0.4. Th. shoulder at handle attachment level 0.6. O: 5YR5/8 yellowish red broadband on upper neck with detached paint zones; similar band on lower neck; reserved zones 10YR8/2 white colour. I: rim and a neck broadband of same colour as outside broadbands; reserved zones as outside. Clay 7.5YR7/8 reddish yellow with calcite and chamotte.

\section{Amphora (Fig. 6.2).}

LN. MN7/1998/35. Pr. 7-13 Méndez Núñez St / 12 Las Monjas Sq. Fr. of rim, neck and shoulder. Everted and square-off rim. H. 6.8. W. 6.6. D. 10.5. H. rim 1.1. H. neck 5.1. Th. rim 0.75. Th. neck 0.5. Th. shoulder at lower breaking edge 0.35 . O: traces of $2.5 \mathrm{YR} 5 / 8$ red slip; slip detachment zones of same colour as clay. I: reserved same colour as clay. Clay 5YR5/8 yellowish red.

\section{Bowl with graffiti (Fig. 6.3).}

LN. MN7/1998/34a and MN7/1998/34b. Pr. 7-13 Méndez Núñez St / 12 Las Monjas Sq. Two fragments of rim and body, "a" and "b", "a" also includes remain of a handle. Fr. "a": H. 3.3, W. 6. Fr. "b": H. 2.9, W. 4.7. D. 20. Handle cross-section $0.8 \times 1$. Th. body between 0.4 at upper part and 0.35 at lower breaking edge. $\mathrm{O}$ : 2.5YR4/8 red slip remains including handle. I: slipped as outside except for a reserved $2.5 \mathrm{Y} 7 / 4$ pale yellow band below rim. Clay 7.5YR8/4 pink. Graffiti in both "a" and "b" fragments (epigraphic interpretation in Addendum). 


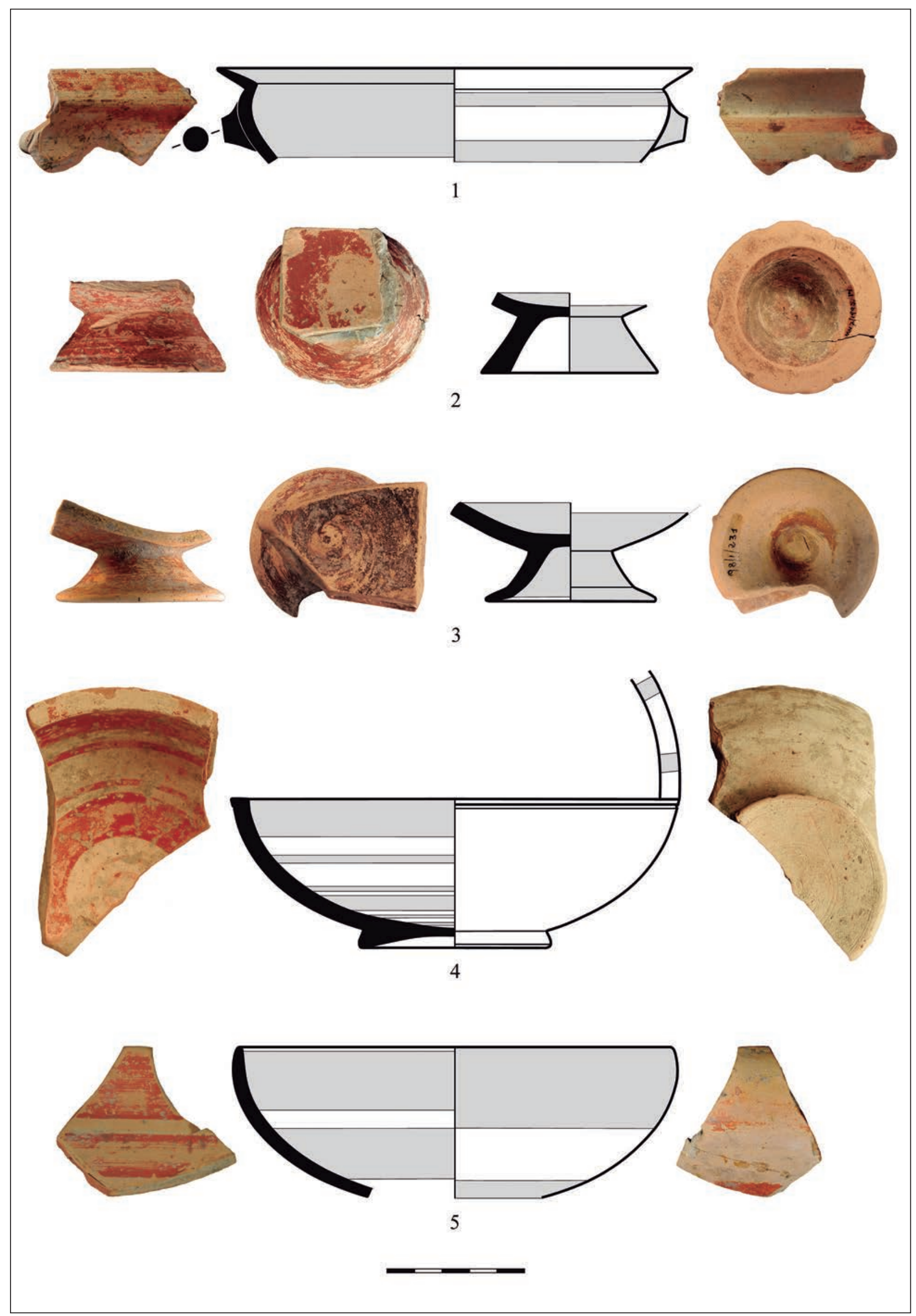

Figure 4. 

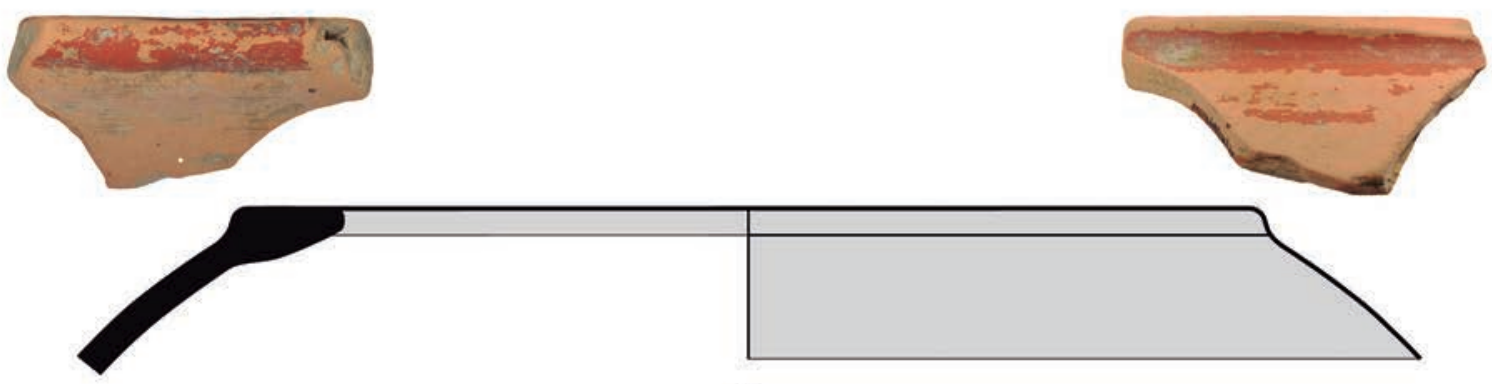

6
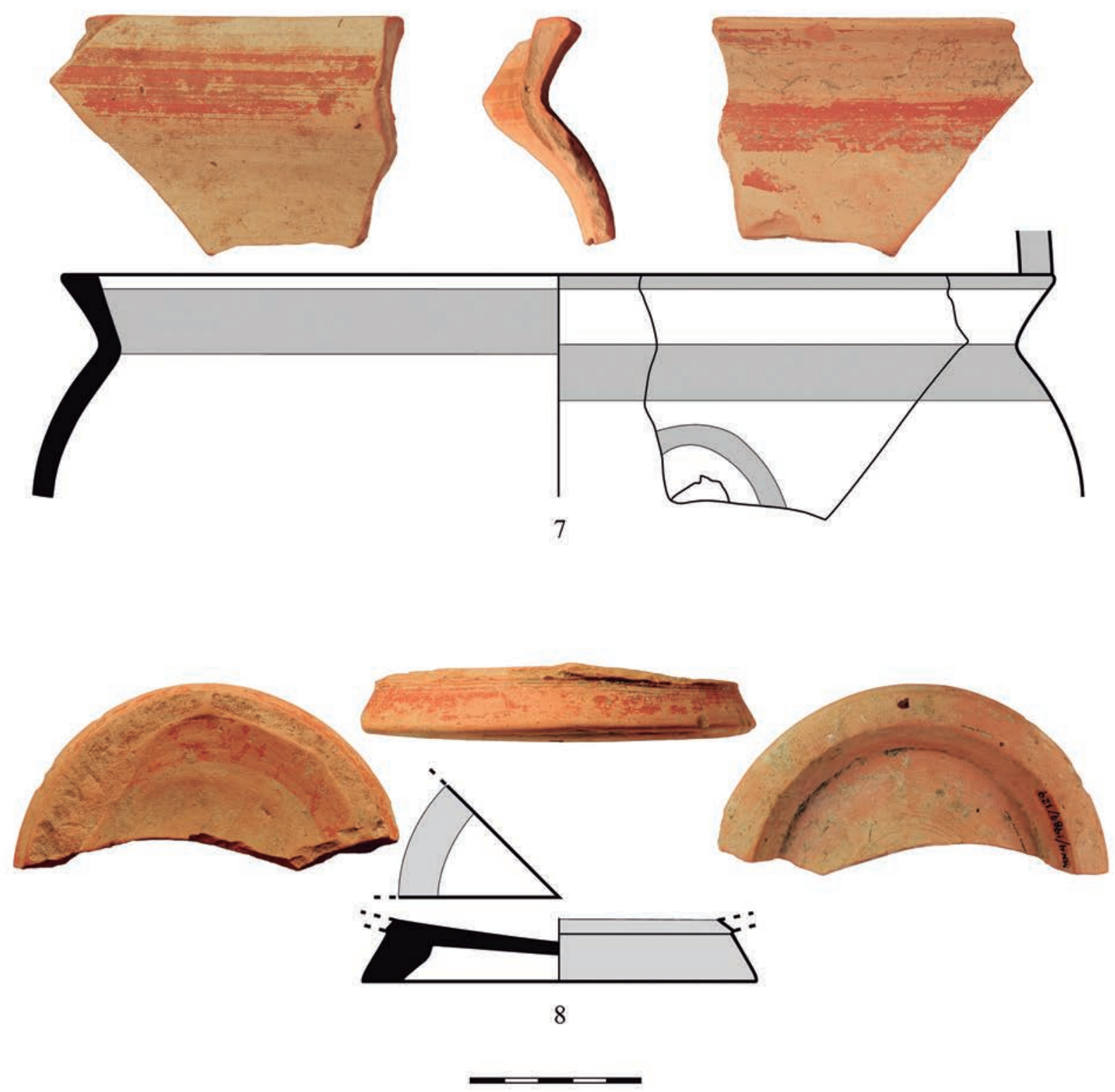

Figure 5. 


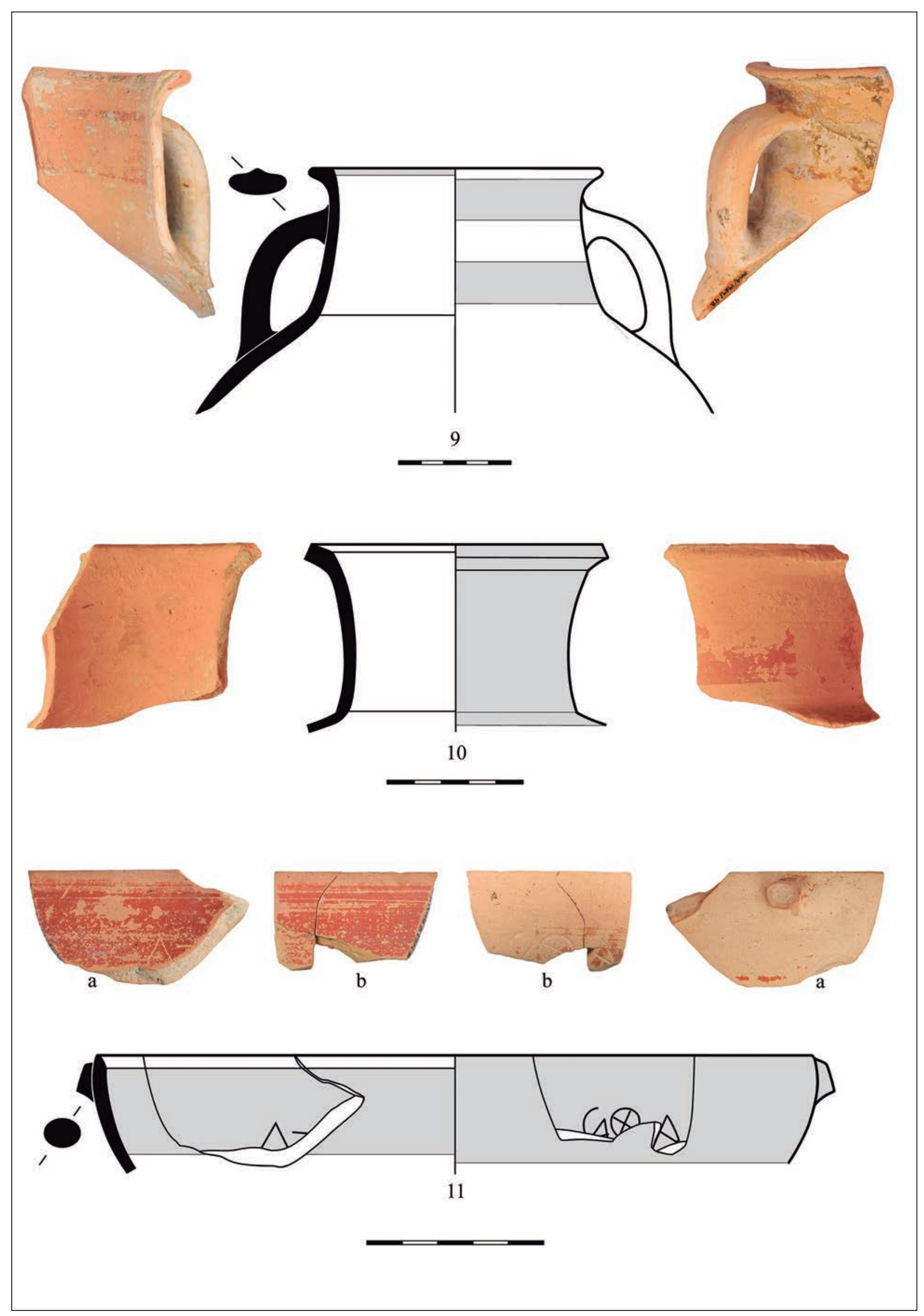

Figure 6. 


\section{ACKNOWLEDGMENTS}

Our gratitude to Pablo Guisande Santamaria, director of the Huelva Museum and his staff for their kind attention; to Enrique Carlos Martín Rodríguez, the Museum curator for his support and permanent motivation; to César Alberto Campos Bayo, for his selfless collaboration with the photographic illustrations; and a very special mention to Juan Carlos Fernández Caliani, Professor of Crystallography and Mineralogy at the University of Huelva, for his advice in the analytical study of the clays, without whose valuable help this paper would not have been possible.

\section{BIBLIOGRAPHY}

Adan-Bayewitz, D., Asaro, F. and Giauque, R.D. (2006): "The discovery of anomalously high silver abundances in pottery from early Roman excavation contexts in Jerusalem". Archaeometry, 48, 3: 377-398. DOI: https://doi.org/10.1111/j.14754754.2006.00262.x

Adan-Bayewitz, D., Slane, K.W., Asaro, F. and Giauque, R.D. (2010): "Silver in ancient pottery: context matters". Journal of RomanArchaeology, 23: 137-160. DOI: https://doi.org/10.1017/S10477 59400002348

Cabrera Bonet, P. (1990): "El comercio foceo en Huelva: cronología y fisionomía". Huelva Arqueológica, X-XI, 3: 41-100.

Domínguez Monedero, A. J. (2010): "Fragmento de copa con inscripción griega", in M. D. López de La Orden and E. García Alfonso (eds.): Catálogo de la Exposición, Cádiz y Huelva: Puertos fenicios del Atlántico. Sevilla: 60-61, n. 10.

Domínguez Monedero, A.J. (2013): "Los primeros griegos en la Península Ibérica (s. IX-VI a.C.): mitos, probabilidades, certezas", in M.P. de Hoz and G. Mora (eds.): El Oriente griego en la Península Ibérica. Epigrafía e Historia. Madrid: 11-42.
González de Canales, F. (2014): "Tarshish-Tartessos, the Emporium Reached by Kolaios of Samos", in A. Lemaire (ed.): Phéniciens d'Orient et d'Occident. Mélanges Josette Elayi. Avec la collaboration de B. Dufour et F. Pfitzmann. Cahiers de l'Institut du Proche-Orient Ancien du Collège de France II. Paris: 559-576.

González de Canales, F. and Llompart, J. (2017): "Producción de cerámicas griegas arcaicas en Huelva". Archivo Español de Arqueología, 90: 125-145. https://doi:10.3989/aespa.090.017.006

An English translation in http://www.academia.edu/ 34966268 (consulted 2 January 2018).

Hoz García-Bellido, M.P. (2014): Inscripciones griegas de España y Portugal (IGEP). Bibliotheca Archaeologica Hispana, 40. Madrid.

Jeffery, L.H. (1990): The Local Scripts of Archaic Greece. A study of the Greek alphabet and its development from the eighth to the fifth centuries B.C. Revised edition with a supplement by A.W. Johnston. Oxford.

Johnston, A.W. (1979): Trade marks on Greek Vases. Warminster.

Olmos Romera, R. and Cabrera Bonet, P. (1980): “Un nuevo fragmento de Clitias en Huelva". Archivo Español de Arqueología, 53: 5-14.

Osuna Ruiz, M., Bedia García, J. and Domínguez Rico, A.M. (2001): "El santuario protohistórico hallado en la calle Méndez Núñez (Huelva)", in P. Cabrera Bonet and M. Santos Retolaza (eds.): Ceràmiques jònies d'època arcaica: centres de producció i comercialització al Mediterrani Occidental: Actes de la Taula Rodona held at Empúries (26-28 May 1999). Monografies Emporitanes 11. Barcelona: 177-188 
